\title{
Evaluation of Clinical Features of 238 Cases with Febrile Convulsion
}

\author{
Febril Konvülziyonlu 238 Olgunun Klinik Özelliklerinin Değerlendirilmesi
}

Mesut Koçak ${ }^{1}$, Ebru Yılmaz ${ }^{2}$, Osman Özdemir ${ }^{1}$, Yusuf Aydın ${ }^{3}$, Ali Osman Köksal ${ }^{1}$, Deniz Yılmaz ${ }^{1}$, Aslıhan Araslı Yılmaz ${ }^{1}$

${ }^{1}$ Department of Pediatrics, Kecioren Training and Research Hospital, Ankara, Turkey
${ }^{2}$ Department of Family Medicine, Atatürk Training and Research Hospital, Ankara, Turkey
${ }^{3}$ Department of Family Medicine, Kecioren Training and Research Hospital, Ankara, Turkey

\section{ABSTRACT}

Objective: Febrile convulsion (FC) is defined as a seizure triggered by fever in children between 6 months and 5 years of age without an underlying central nervous system infection. In this study, we aimed to evaluate clinical features including demographics, laboratory findings, and causes of fever with FC duration among inpatients diagnosed and treated for FC.

Methods: A total of 238 patients with the diagnosis of FC between May 2009 and May 2012 were included in the study. Demographic, clinical, and laboratory data of the patients were analyzed.

Results: One hundred and thirty nine patients $(58.5 \%)$ were male and 99 $(41.5 \%)$ were female, with a male/female ratio of 1.4 . Mean age of the patients admitted with a first FC was $2.2 \pm 1.1$ years. The mean temperature of the patients measured rectally during the seizure was $38.7 \pm 0.5 \stackrel{\circ}{ } \mathrm{C}$. Febrile convulsion was diagnosed as simple type in $198(83.2 \%)$ and complex type in $40(16.8 \%)$ of the patients. Thirty three $(13.8 \%)$ patients developed a second seizure within 24 hours. Median convulsion duration was 2 (1-5) minutes. The most frequent fever etiology was upper respiratory tract infection in $131(55 \%)$ cases.

Conclusion: This study demonstrated that benign conditions, such as upper respiratory tract infections, were common causes of FC. A conservative approach should be more appropriate in these cases.

Key words: Children, epilepsy, febrile convulsion, fever, seizure, upper respiratory tract infections

Received: 04.12.2014
Accepted: 05.16.2013
ÖZET

Amaç: Febril konvülziyon (FK) altta yatan bir merkezi sinir sistemi enfeksiyonu olmayan 6 ay ile 5 yaş arasındaki çocuklarda ateşin tetiklediği bir nöbet olarak tanımlanmaktadır. Bu çalışmada, FK tanısı konulan ve tedavi edilen hastaların demografik özellikleri, laboratuar bulguları ve ateş sebepleri ile FK süresini içeren klinik özelliklerini değerlendirmeyi amaçlanmıştır.

Yöntem: Mayıs 2009 ve Mayıs 2012 tarihleri arasında FK tanısı konulan 238 hasta çalışmaya alınmıştır. Bu olguların demografik, klinik ve laboratuar verileri değerlendirilmiştir.

Bulgular: Yüz otuz dokuz hasta $(\% 58,5)$ erkek ve $99^{\prime} u(\% 41,5)$ kız olup erkek/kız oranı 1,4 bulunmuştur. İlk kez FK ile getirilen hastaların yaş ortalamasının $2,2 \pm 1,1$ olduğu görülmüştür. Hastaların nöbet sırasında rektumdan ölçülmüş olan ortalama vücut sıcaklıkları $38,7 \pm 0,5^{\circ} \mathrm{C}$ bulunmuştur. Febril konvülziyonlu hastaların $198^{\prime}$ ine basit tip $(\% 83,2)$ ve $40^{\prime}$ ına kompleks tip $(\% 16,8)$ tanısı konulmuştur. Otuz üç $(\% 13,8)$ hastada 24 saat içinde ikinci bir nöbet meydana gelmiştir. Ortanca konvülziyon süresi 2 (1-5) dakika hesaplanmıştır. En sık ateş etiyolojisinin 131 (\%55) olguda saptanan üst solunum yolu enfeksiyonu olduğu görülmüştür.

Sonuç: Bu çalışma, üst solunum yolu enfeksiyonları gibi benign durumların, FK'nın sık nedenleri olduğunu göstermiştir. Bu nedenle bu olgularda yapılacak konservatif yaklaşım daha uygundur.

Anahtar Sözcükler: Çocuk, epilepsi, febril konvülziyon, ateş, nöbet, üst solunum yolu enfeksiyonları

Geliş Tarihi:12.04.2014

Kabul Tarihi: 16.05 .2014 


\section{INTRODUCTION}

Febrile convulsion (FC) is defined as a seizure induced by fever in children between 6 months and 5 years of age without an underlying central nervous system infection $(1,2)$. It is the most common childhood convulsive disease; and $3-4 \%$ of children experience $\mathrm{FC}$ at least once up to 7 years of age (1-4).

Febrile convulsion incidence varies between 2-4\% (2-4). Boys are more susceptible to FC as compared with girls with a ratio of 1.4/1.2 (4). Although it is known to have a genetic basis, mode of inheritance is not yet clear. Various genetic models including multifactorial inheritance, autosomal dominant inheritance with incomplete penetration or polygenic inheritance have been proposed (5). In children with positive family history, polymorphism in voltage-gated sodium channel subunit (SCN1A, SCN1B, SCN2A) and gamma-amino butyric acid (GABA) (A) receptor subunit (GABRG2, GABRD) genes were reported $(6,7)$. On the other hand, pathogenesis of FC is not also clearly documented. In various studies, increased serum interferon- $\alpha$ and neuron-specific enolase levels, decrease in thyroid stimulating hormone and cortisol levels, impaired central thermoregulation, delay in central nervous system maturation, increase in excitatory aminoacids, presence of iron deficiency anemia and zinc deficiency were shown; however, their roles in FC pathogenesis are controversial (5-7).

There are three types of febrile seizures: simple FC, complex FC, and febrile status epilepticus. Recurrence may be seen and the average risk of recurrence is around $30-40 \%$ (8). The major risk factors for recurrence are the first FC under the age of 15 months, positive family history, and a complex type first seizure. However, in general, FC is a benign condition and the prognosis is good (1). In this study, we aimed to identify the clinical features among $238 \mathrm{FC}$ cases.

\section{METHODS}

A total of 238 patients with the diagnosis of FC between May 2009 and May 2012 were included in the study. Demographics, clinical, and laboratory data, type and duration of FC, treatments of FC, and etiology of fever were retrospectively analyzed. Clinical features of the patients with FC were also evaluated.

The accepted criteria for FC include: presence of fever together with the convulsion, age between 3 months and 5 years, no history of previous afebrile convulsions, and absence of any neurological abnormality, metabolic or toxic encephalopathy or intracranial pathology (1-4). Patients with a history of previous afebrile convulsion, and presence of any neurological abnormality, metabolic or toxic encephalopathy or intracranial pathology were excluded. If the tympanic body temperature was $>38^{\circ} \mathrm{C}$ and the duration of the seizure was $<15$ minutes, it was classified as simple FC, while convulsions that lasted longer than 15 minutes, and recurred during the same disease with focal features were diagnosed as complex FC.

The 18-channel digital electroencephalography (EEG) (Nihon Kohden Corporation Electroencephalography Model EEG-1200K, 2008, Tokyo, Japan) was obtained from the selected patients at least 3 weeks after FC. Recordings of EEG were performed after sleep-deprivation and a standard 20-30 minutes protocol was used, which included hyperventilation and photic stimulation.

\section{Statistical analysis}

Statistical Package for Social Sciences (SPSS) 15.0 (SPSS Inc., Chicago, IL, USA) statistical software package was used for the evaluation of the variables and the tests. Those with normal distribution among the numeric variables were given as mean \pm standard deviation and those without normal distribution were given as median (minimum-maximum) whereas categorical variables were given in percentages.

\section{RESULTS}

Of the 238 patients diagnosed with FC, 139 (58.4\%) were male and 99 $(41.6 \%)$ were female, with a male/female ratio of 1.4. Mean age of patients admitted with a first FC was $2.2 \pm 1.1$ years. Characteristics of the patients with febrile convulsion are shown in Table 1.
Table 1. Characteristics of the patients with febrile convulsion

\begin{tabular}{lll}
\hline Patients characteristics & $\mathbf{n}$ & $\%$ \\
\hline Male/female ratio & $1.4(139 / 99)$ & $58.4 / 41.6$ \\
$\begin{array}{l}\text { Simple/complex type FC } \\
\text { Number of second seizure within } 24\end{array}$ & $198 / 40$ & $83.2 / 16.8$ \\
hours & 33 & 13.8 \\
Previous FC history & 72 & 30.2 \\
Positive FC history in the family & 98 & 41.2 \\
Number of EEG & 48 & 20.2 \\
Number of epileptic activity in EEG & 5 & 2.1 \\
\hline
\end{tabular}

EEG: Electroencephalography, FC: Febrile convulsion.

Febrile convulsion was found as simple type in 198 (83.2\%) and complex type in $40(16.8 \%)$ patients upon their admission to the emergency department. Thirty three $(13.8 \%)$ patients developed a second seizure within 24 hours. Average convulsion duration was 2 (2-5) minutes.

There was positive FC history in the family of 98 (41.2\%) cases. Furthermore, $72(30.2 \%)$ of the children had previous FC history.

The mean temperature of the patients measured rectally during the sei-

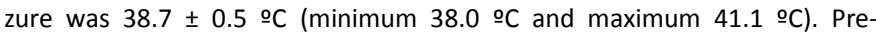
convulsive febrile duration was found $0-12$ hours for 128 patients $(53.8 \%)$, $12-24$ hours for 47 patients (19.7\%), 24-48 hours for 22 patients (9.3\%), and was unknown for 41 patients (17.2\%).

Seventy eight $(32.8 \%)$ patients with prolonged seizure received nasal or intravenous midazolam. Rectal diazepam was applied to 58 patients (24.4\%). Electroencephalography was performed in 48 patients (20.2\%), and only 5 of them (2.1\%) had epileptic activity.

The most frequent fever etiology was upper respiratory tract infection in $131(55.0 \%)$ cases, followed by acute otitis media in $34(14.3 \%)$. We were not able to detect the origin of fever in 15 cases (6.3\%). Fever etiology and underlying infectious diseases in the patients with febrile convulsion are shown in Table 2.

Table 2. Underlying infectious diseases in the patients with febrile convulsion.

\begin{tabular}{lll}
\hline Infectious diseases & $\mathbf{n}$ & $\mathbf{\%}$ \\
\hline Upper respiratory tract infection & 131 & 55.0 \\
Acute otitis media & 34 & 14.3 \\
Lower respiratory tract infection & 15 & 6.3 \\
Fever of unknown origin & 15 & 6.3 \\
Viral eruptive disease of childhood & 15 & 6.3 \\
Urinary tract infection & 14 & 5.9 \\
Acute gastroenteritis & 14 & 5.9 \\
Total & 238 & 100 \\
\hline
\end{tabular}

\section{DISCUSSION}

Febrile convulsion is the most common type of seizure in childhood. Of all seizures, approximately $65-90 \%$ is febrile convulsions (9). Febrile convulsion incidence among children younger than 5 years of age in Europe and the United States of America is around 2-4\%. This rate goes up to $14 \%$ in Asian countries (3). However, there is not enough information about FC incidence in Turkey.

Although it affects children between 6 and 60 months of age, FC peaks during the second year, with peak incidence between 18 to 22 months $(3,8)$. In our study, the mean FC age was in accordance with the literature. In many studies, boys were shown to have FC more frequently than girls with a ratio of 1.1-2.4/1 (1). We also detected a predominance of boys with a ratio of $1.4 / 1$ in our study. This ratio is in line with the other studies in our country (10-12).

The main cause of FC is not clearly documented, but it is thought to be multifactorial. Studies have shown that both genetic and environmental factors contribute to the pathogenesis (13). Despite increasing evidence in favor of an association between family history and FC, the inheritance mode is unknown. In some families, polygenic inheritance has been found, while in others with a lesser incidence, there may be autosomal dominant inheritance (13). In addition, susceptibility to FC may be seen in some families due to genetic mutations in some genes (14-16). Medical literature indicate positive family history of FC in $25-40 \%$; that is $9-22 \%$ among siblings $(17,18)$. In national publications, this percentage varies between $4-35 \%(10,12,19)$. Being in line with the literature, positive family history was found to be $41.1 \%$ in our study. 
Simple FC is more common than complex FC. Similarly, the distribution pattern of FC types as simple FC in $83.2 \%$ and complex FC in $16.8 \%$ in this study is in accordance with other studies that range between $69-89.8 \%$ for simple, and $10.2-31 \%$ for complex FC (10-12). In Sweney's study, $90.9 \%$ of the FC was found of simple type (20).

In $80 \%$ of the FC patients, seizure duration is below 10 minutes, and in less than $9 \%$ it is longer than 15 minutes (21). Median FC duration was found as 2 minutes in our study. Thirty three (13.8\%) patients developed a second FC within the first 24 hours at the hospital. However, we have no information about long-term repetition(s). In a cohort study, it was reported that in $32 \%$ of the patients a recurrence was observed, and $78 \%$ of the repetitions were within a year (22). The overall recurrence rate is $30 \%$. Risk factors for recurrence of febrile seizures are lower temperature, shorter duration of recognized temperature before FC, family history of FC, and age younger than 18 months. Main prognostic factors for the development of epilepsy after FC are complex FC, positive family history of epilepsy, and multiple episodes of FC $(23,24)$. Unfortunately, long-term follow-up of our patients was not recorded to evaluate the recurrence rate or the development of epilepsy.

Risk factors including onset of FC before 15 months of age, FC history in first degree relatives, and seizure occurrence at a low body temperature or shortly after the onset of fever have been described. In addition, FC history at an early age is another important risk factor. Besides, FC incidence among children with a positive family history in first and second degree relatives, and attending nursery school seems to increase. Another risk factor for FC to be kept in mind is family history of epilepsy. Febrile convulsion was observed in $12 \%$ of children without any risk factor, in $25 \%$ of those with one, in $50 \%$ with 2 , and $80-100 \%$ with 2 or more risk factors (22). In previous studies 18 $25 \%$ of all children with a first febrile seizure had a first degree relative affected by febrile seizures $(25,26)$. In others, there was a family history of febrile seizures in $30 \%$ and $57 \%(27,28)$. In our study, $30.2 \%$ of FC patients had positive FC history but some of them were not first degree relatives.

Upper respiratory tract infection, which is the most frequent cause of fever in the population, was also the most common source of fever in our patients; followed by acute otitis media, lower respiratory tract infection and occult bacteremia. The order of fever origin was in line with the literature $(12,19)$. The role of viral infections in the etiology of FC is related to the degree of fever and is a common disorder underlying FC. Human herpes virus 6 (especially during the first 2 years of age), influenza, adenovirus, and parainfluenza virus infections are frequently associated with either simple or complex FC (29).

The possibility that immunizations may cause FC is another potential concern. Inactive trivalent influenza, diphtheria, tetanus toxoid, pertussis, and mumps, measles and rubella (MMR) vaccines increase risk of FC $(30,31)$. In a systematic review by Cochrane group, risk of FC within 2 weeks after MMR vaccination has been documented. Children had FC associated with vaccine-induced fever at a rate of 1-2 seizures per 1000 vaccinations (32).

Electroencephalography is of limited value in the management of FC. According to American Academy of Pediatrics guidelines, neuroimaging and EEG are not indicated after simple FC in healthy children (33). Because complex FC is associated with increased risk of development of subsequent epilepsy, EEGs tend to be ordered more in these patients. Clinicians most often perform EEG because of parental demand or to predict FC recurrence or epilepsy (34). In a study with all randomized controlled trials that examined the utility of an EEG and its timing after complex febrile seizures in children, no evidence was found to support or refute the use of EEG and its timing after complex febrile seizures among children (35). Interictal EEG is usually normal; postictal EEG may reveal bilateral posterior slow activity. Focal or asymmetric slow activity may indicate that the seizure is focal or lateralized. In children with FC, even postictal EEG was found to be normal in $68-90 \%$ of the cases (36). In our study, EEG was performed in 48 cases and only 5 of them showed abnormality. In other words, $90 \%$ of the children who undergone EEG was found to be normal; and, that was in line with the literature.

If the patient's first FC is complex, there is a possibility of an underlying central nervous system infection, and if he/she is younger than 12 months, the findings of meningeal irritation may not be evident; therefore lumbar puncture is recommended by American Academy of Pediatrics (1). In children older than 12 months, lumbar puncture should be considered if only there are meningeal irritation signs.
Although FC mostly recovers in a short period of time, physicians should be alerted about the possible development of febrile status. In general, agents such as midazolam and diazepam are preferred, but in a review article by Cochrane group, lorazepam was reported to be as effective as diazepam; and moreover, the need for an additional antiepileptic was lesser (37). In the same study, it was shown that in case of prolonged seizures, if intravenous route was not available, buccal midazolam was superior to rectal diazepam. In our study, midazolam was used to control the seizure in 78 patients. According to a report with thirty-six articles describing 26 randomized trials with 2740 randomized participants, no clinically important benefits for children with febrile seizures were found for intermittent oral diazepam, phenytoin, phenobarbitone, intermittent rectal diazepam, valproate, pyridoxine, intermittent phenobarbitone or intermittent ibuprofen, nor for diclofenac versus placebo followed by ibuprofen, acetominophen or placebo (38).

Particularly simple FC is short lasting by nature and the mortality rate is very low. Families should be informed about this fact since they panic when their child is having an FC; that is an important task for the physician. Another issue is the long term effect of FC on the child's intelligence. In a study, it was found that FC was not associated with a decrement in intelligence quotient or early academic performance, as judged by comparison of affected children with their siblings (39). Families should also be informed that the seizures may recur. Furthermore, they should be taught how to protect their child from infections and what to do in case of a fever in details.

\section{CONCLUSION}

This study demonstrated that benign conditions such as upper respiratory tract infections were common causes of FC. Conservative approach should be more appropriate in these cases.

\section{Conflict of Interest}

No conflict of interest was declared by the authors.

\section{REFERENCES}

1. Steering Committee on Quality Improvement and Management, Subcommittee on Febrile Seizures American Academy of Pediatrics. Febrile seizures: clinical practice guideline for the long-term management of the child with simple febrile seizures. Pediatrics 2008; 121: 1281-6.

2. Commission on Epidemiology and Prognosis, International League Against Epilepsy. Guidelines for epidemiologic studies on epilepsy. Epilepsia 1993; 34: 592-6.

3. Hauser WA. The prevalence and incidence of convulsive disorders in children. Epilepsia 1994; 35 Suppl 2: S1-6.

4. Fetveit A. Assesment of febrile seizures in children. Eur J Pediatr 2008; 167: 17-27.

5. Rich SS, Annegers JF, Hauser WA, Anderson VE. Complex segregation analysis of febrile convulsions. Am J Hum Genet 1987; 41: 249-57.

6. Nakayama J, Arinami T. Molecular genetics of febrile seizures. Epilepsy Res 2006;70 Suppl 1: S190-8.

7. Nakayama J. Progress in searching for febrile seizure susceptibility genes. Brain Dev 2009; 31: 359-65.

8. Farwell JR, Blackner G, Sulzbacher S, Adelman L, Voeller M. First febrile seizures. Characteristics of the child, the seizure, and the illness. Clin Pediatr (Phila) 1994; 33: 263-7.

9. Wairuiru C, Appleton R. Febrile seizures: an update. Arch Dis Child 2004; 89: 751-6.

10. Ozaydın E, Yasar MZ, Guven A, Degerliyurt A, Vidinlisan S, Kose G. Clinical features and risk factors in 1385 febrile convulsion cases [Turkish article]. Turkish J Pediatr Dis 2011; 5: 11-8.

11. Sen Y, Sengul I, Arslan N, Kabakus N. Febrile convulsions: analysis of 265 cases [Turkish article]. Turkiye Klinikleri J Pediatr 2008; 17: 75-9.

12. Aygun $A D$, Guvenc $H$, Koc A. First febrile convulsion: evaluation of 169 cases [Turkish article]. T Klin Pediatr 1995; 4: 16-9.

13. Iwasaki N, Nakayama J, Hamano K, Matsui A, Arinami T. Molecular genetics of febrile seizures. Epilepsia 2002; 43 Suppl 9: 32-5.

14. Audenaert D, Van Broeckhoven C, De Jonghe P. Genes and loci involved in febrile seizures and related epilepsy syndromes. Hum Mutat 2006; 27: 391-401. 
15. Johnson EW, Dubovsky J, Rich SS, O'Donovan CA, Orr HT, Anderson VE, Gil-Nagel A, Ahmann P, Dokken CG, Schneider DT, Weber JL. Evidence for a novel gene for familial febrile convulsions, FEB2, linked to chromosome 19p in an extended family from the Midwest. Hum Mol Genet 1998; 7: 63-7.

16. Gérard F, Pereira S, Robaglia-Schlupp A, Genton $P$, Szepetowski $P$. Clinical and genetic analysis of a new multigenerational pedigree with GEFS+ (Generalized Epilepsy with Febrile Seizures Plus). Epilepsia 2002; 43: 581-6.

17. Hauser WA, Annegers JF, Anderson VE, Kurland LT. The risk of seizure disorders among relatives of children with febrile convulsions. Neurology 1985; 35: 1268-73.

18. Doose $H$, Maurer A. Seizure risk in offspring of individuals with a history of febrile convulsions. Eur J Pediatr 1997; 156: 476-81.

19. Aydın OF, Senbil N, Kara C, Bozkurt C, Gurer YKY. Retrospective evaluation of 201 cases with febrile convulsion [Turkish article]. Ankara Universitesi Tip Fakultesi Mecmuasi 2000; 53: 231-5.

20. Sweeney A, Gibbs J, Monteil F, Appleton R, Choonara I. The management of febrile seizures in the Mersey region. Dev Med Child Neurol 1996; 38: 578-84.

21. Berg AT, Shinnar S. Unprovoked seizures in children with febrile seizures: short-term outcome. Neurology 1996; 47: 562-8.

22. Berg AT, Shinnar S, Darefsky AS, Holford TR, Shapiro ED, Salomon ME, Crain EF, Hauser AW. Predictors of recurrent febrile seizures. A prospective cohort study. Arch Pediatr Adolesc Med 1997; 151: 371-8.

23. Pavlidou E, Panteliadis C. Prognostic factors for subsequent epilepsy in children with febrile seizures. Epilepsia 2013; 54: 2101-7.

24. Hesdorffer DC, Shinnar S, Lewis DV, Nordli DR Jr, Pellock JM, Moshé SL, Shinnar RC, Litherland C, Bagiella E, Frank LM, Bello JA, Chan S, Masur D, Macfall J, Sun S; Consequences of Prolonged Febrile Seizures in Childhood (FEBSTAT) Study Team. Risk factors for febrile status epilepticus: a case-control study. J Pediatr 2013; 163: 1147-51.

25. van Esch A, Steyerberg EW, Berger MY, Offringa M, Derksen-Lubsen G, Habbema JD. Family history and recurrence of febrile seizures. Arch Dis Child 1994; 70: 395-9.

26. Berg AT, Shinnar S, Hauser WA, Alemany M, Shapiro ED, Salomon ME, Crain EF. A prospective study of recurrent febrile seizures. N Engl J Med 1992; 327: 1122-7.

27. Tosun A, Koturoglu G, Serdaroglu G, Polat M, Kurugol Z, Gokben S, Tekgul H. Ratios of nine risk factors in children with recurrent febrile seizures. Pediatr Neurol 2010; 43: 177-82.
28. Veisani Y, Delpisheh A, Sayehmiri K. Familial history and recurrence of febrile seizures; a systematic review and meta-analysis. Iran J Pediatr 2013; 23: 389-95.

29. Chung B, Wong V. Relationship between five common viruses and febrile seizure in children. Arch Dis Child 2007; 92: 589-93.

30. Barlow WE, Davis RL, Glasser JW, Rhodes PH, Thompson RS, Mullooly JP, Black SB, Shinefield HR, Ward JI, Marcy SM, DeStefano F, Chen RT, Immanuel V, Pearson JA, Vadheim CM, Rebolledo V, Christakis D, Benson PJ, Lewis N; Centers for Disease Control and Prevention Vaccine Safety Datalink Working Group. The risk of seizures after receipt of whole-cell pertusis or measles, mumps and rubella vaccine. N Engl J Med 2001; 345: 656-61.

31. Centers for Disease Control and Prevention (CDC). Update: Recommendations of the Advisory Committee on Immunization Practices (ACIP) regarding use of CSL seasonal influenza vaccine (Afluria) in the United States during 2010-11. MMWR Morb Mortal Wkly Rep 2010; 59: 989-92.

32. Demicheli V, Rivetti A, Debalini MG, Di Pietrantonj C. Vaccines for measles, mumps and rubella in children. Cochrane Database Syst Rev 2012; 2: CD004407.

33. Subcommittee on Febrile Seizures; American Academy of Pediatrics. Neurodiagnostic evaluation of the child with a simple febrile seizure. Pediatrics 2011; 127: 389-94.

34. Jeong $\mathrm{KA}$, Han $\mathrm{MH}$, Lee $\mathrm{EH}$, Chung $\mathrm{S}$. Early postictal electroencephalography and correlation with clinical findings in children with febrile seizures. Korean J Pediatr 2013; 56: 534-9.

35. Shah PB, James $S$, Elayaraja S. EEG for children with complex febrile seizures. Cochrane Database Syst Rev 2014; 1: CD009196.

36. Millichap JG, Madsen JA, Aledart LM. Studies in febrile seizures. V. Clinical and electroencephalography, forth edition. Billings and Sons Ltd. London and Guildford, 1981.

37. Appleton R, Macleod S, Martland T. Drug management for acute tonicclonic convulsions including convulsive status epilepticus in children. Cochrane Database Syst Rev 2008; 3: CD0001905.

38. Offringa $M$, Newton R. Prophylactic drug management for febrile seizures in children. Cochrane Database Syst Rev 2012; 4: CD003031.

39. Ellenberg JH, Nelson KB. Febrile seizures and later intellectual performance. Arch Neurol 1978; 35: 17-21. 